\title{
Physical analysis of peduncles of dwarf cashew clones for consumption, processed or natural
}

\section{Análisis físico de pedúnculos en clones de anacardio enano para consumo en fresco y procesado}

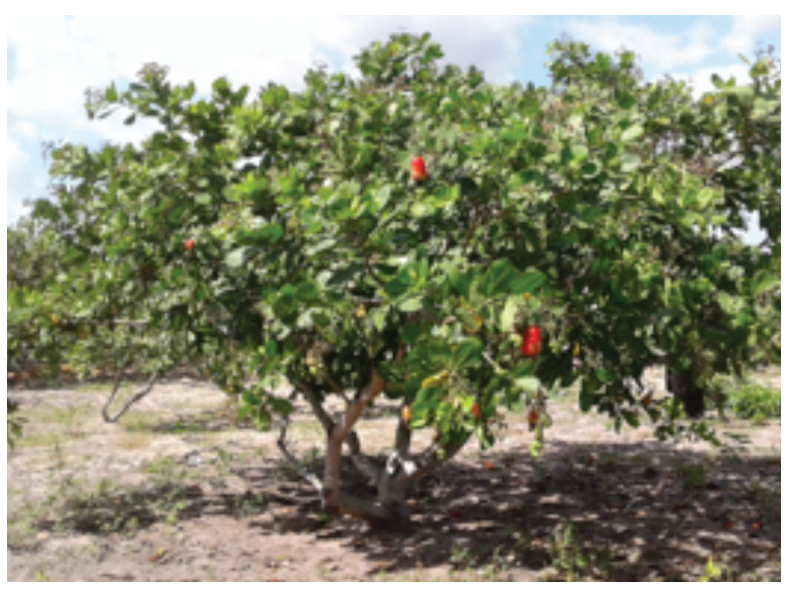

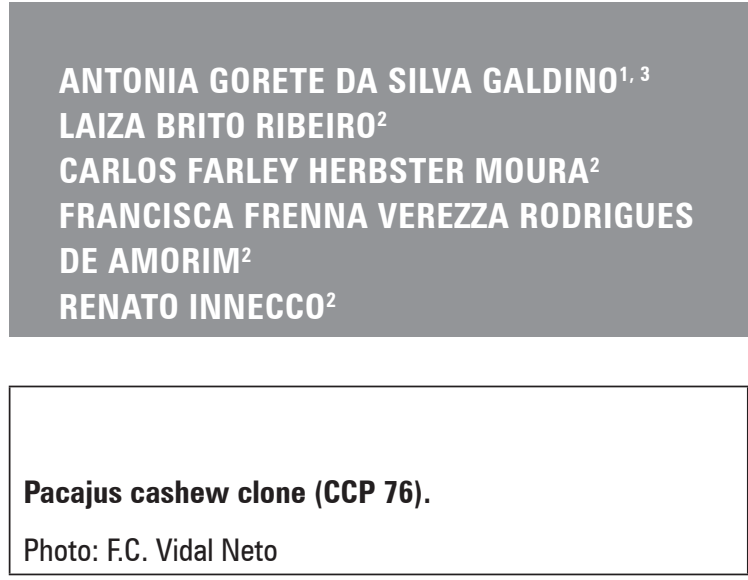

\section{ABSTRACT}

The physical characteristics of cashew-dwarf peduncles were evaluated to later indicate the best clones for natural consumption and/or processing, considering that consumers appreciate products for their visual attractiveness. The objective of this study was to analyze peduncles of dwarf cashew clones obtained from the Genetic Improvement Program of Embrapa Agroindústria Tropical, Cruz-CE experimental area, in order to make inferences about the physical characteristics and indicate the best clones for natural consumption and/ or processing. The analyzed variables were: total mass of the cashew (MT), chestnut mass (MC), peduncle mass (MP), apical diameter (DA), basal diameter (DB), length and firmness. The experiment design was a randomized complete block design with 25 treatments (clones) with 3 replications and up to 12 cashews per plot (four plants in total). The analysis of variance and the comparison of the means by the Scott and Knott test was realized. When analyzing the MT values, it was found that $100 \%$ of the clones were classified as types 4 (approximately $150 \mathrm{~g}$ ), 5 (approximately $120 \mathrm{~g}$ ) and 6 (approximately $80 \mathrm{~g}$ ) cashews/tray, except 149-1. As for MC, there was a variation from 8.18 to $15.08 \mathrm{~g}$. General averages of $95.16,50.07$ and $41.38 \mathrm{~mm}$ were found for the variables length, DB and DA of peduncle, respectively. It is concluded that, in general, all clones presented good characteristics; however, clone 108-6 is the preference for most consumers since it has red staining, as did the control (CCP 76). Therefore, all clones presented desirable characteristics for natural consumption and/or processing.

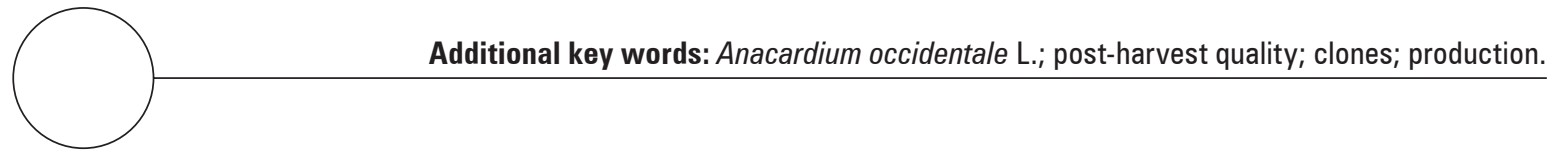

1 Universidade Federal de Viçosa, Departamento de Fitotecnia, Viçosa (Brazil). ORCID Galdino, A.: 0000-0001-50142654

2 Universidade Federal do Ceará, Centro de Ciências Agrárias; Embrapa Agroindústria Tropical, Fortaleza (Brazil). ORCID Ribeiro, L.B.: 0000-0002-4998-6937; ORCID Moura, C.: 0000-0002-6309-509X; ORCID Amorim, F.F.V.R.: 0000-0002-9547-3577; ORCID Innecco, R.: 0000-0002-0992-8142

3 Corresponding author. antonia_galdino17@hotmail.com 


\section{RESUMEN}

Se evaluaron las características físicas de los anacardos enanos, considerando que los consumidores primero aprecian los productos por su atractivo visual. Este trabajo tuvo como objetivo analizar pedúnculos de clones de anacardos enanos obtenidos del Programa de Mejoramiento Genético de la Agroindustria Embrapa, realizado en el área experimental de Cruz-CE, con el propósito de hacer inferencias sobre sus características físicas, para luego indicar los mejores clones destinados al consumo fresco y / o procesamiento. Las variables analizadas fueron: masa total de anacardo (MT), masa de nuez (MN), masa del pedúnculo (MP), diámetro apical (DA), diámetro basal (DB), longitud y firmeza. El diseño experimental fue en bloques al azar con 25 tratamientos (clones) con 3 repeticiones, y se cosecharon hasta 12 anacardos por parcela (la parcela tenía un total de cuatro plantas). Se realizó un análisis de varianza y comparación de medias con la prueba de Scott y Knott. Al analizar los valores de MT, se encontró que el 100\% de los clones se clasificaron como tipo 4 (aproximadamente $150 \mathrm{~g}$ ), 5 (aproximadamente $120 \mathrm{~g}$ ) y 6 (aproximadamente 80 g) anacardos/bandeja, excepto 149-1. En cuanto a la MN hubo una variación de 8,18 a 15,08 g. Promedios generales de 95,$16 ; 50,07$ y $41,38 \mathrm{~mm}$, para las variables longitud, DB y DA del pedúnculo, respectivamente. Se concluye que, en general, todos los clones mostraron buenas características, sin embargo, el clon 108-6 es de mayor preferencia para los consumidores, ya que presenta color rojo como el control (CCP 76). Por lo tanto, todos los clones mostraron características deseables para el consumo y/o procesamiento fresco.

Palabras clave adicionales: Anacardium occidentale L.; calidad poscosecha; clones; producción.

Received for publication: 23-05-2019 Accepted for publication: 31-07-2019

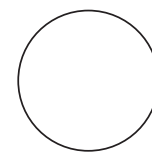

Physical variables such as appearance, size, color, shape, firmness are of great importance since they are the main characteristics that attract consumers. However, one should seek to meet the requirements of the intended market according to their needs, depending on the type of product to be obtained from the selected clone (Almeida et al., 2018). Qualitative attributes such as color, size, firmness and shape are more important than quantitative ones in physical analyses because they assist in the establishment of the fruit harvest point (Lopes, 2011).

Moreover, these are of great importance in marketing since they are the main characteristics available to consumers, who prioritize buying fruits that visibly have a more attractive appearance. Fruit quality is genetically established, so there is no human intervention because quality is determined by the capacity of genes. However, for expression to occur at the full genetic potential, plants are subject to several factors, such as nutritional requirements and appropriate soil and climatic conditions (Aular and Natale, 2013).

Nutrients and minerals interfere significantly with fruit quality and productivity, where soil fertility is one of the main factors for the development of the genetic potential of plants. Considering that a chemical analysis of the soil is necessary in order to characterize its capacity to provide nutrients, so that, each type of soil can be suitable for the cultivar to be produced (Wang et al., 2015).

In order to meet the main interest in the final product, the desirable characteristics for a clone to present good peduncle production are: low plant size to facilitate manual harvesting and to avoid damage the product; peduncle with color ranging from orange to red, pyriform shape, masses ranging from 100 to $140 \mathrm{~g}$ and have good firmness (Moura et al., 2015). Therefore, the objective of this study was to evaluate peduncles of different clones of dwarf-cashew in order to infer the physical characteristics for later indication for natural consumption and/or processing.

\section{MATERIAL AND METHODS}

The cashews (peduncle and chestnut) from dwarf cashew clones came from an experimental unit that is being evaluated in an experiment on competition of 
dwarf cashew clones in Cruz - CE, in the microregion of the Coast of Camocim and Acarau mesoregion, do Noroeste Cearense, with the geographical coordinates: Latitude: $02^{\circ} 55^{\prime} 04^{\prime \prime}$ S and Longitude: $40^{\circ} 10^{\prime} 18^{\prime \prime}$ $\mathrm{W}$, average rainfall: $1,136 \mathrm{~mm}$ and average temperature: $23.0^{\circ} \mathrm{C}$.

This experiment was conducted under field conditions from September 2017 to September 2018. The experiment design was a randomized block, with 25 treatments (Tab. 1) with 4 plants and three replications. The treatments consisted of different dwarf cashew clones that were previously selected based on the local edaphic and climatic conditions, with CCP 76 as a control. CCP 76 was chosen as a control because its features are considered the industry standard: good palatability, good proportion of soluble solids, titratable acidity, and color that appeals to consumers, etc. Peduncles were harvested at the end of September 2017 in the early hours of the morning and immediately packed in plastic boxes with only one layer of fruits, protecting them from mechanical injuries.

According to the variables: total cashew mass (MT), chestnut mass (MC), peduncle mass (MP), apical diameter $(\mathrm{AD})$, basal diameter $(\mathrm{DB})$, length and firmness, the cashews were characterized, with MT (g) (cashew nuts and peduncle) - measured by weighing each individual fruit on a semianalitic balance; MC (g) - determined after cashew weaning by weighing the cashew nut on a semianalitic balance; MP (g) obtained with the difference between the total mass and the cashew nut mass; length, BD (near cashew nut) and $\mathrm{AD}$ (side opposite side of the cashew nut) of the penducle $(\mathrm{mm})$, measured with a digital caliper; and peduncle firmness $(\mathrm{N})$, determined using a $\mathrm{Mc}$ Cormick model FT 011 with $8 \mathrm{~mm}$ diameter nozzle on two points on opposite sides of the medial part of the peduncle.

The experiment design was a randomized complete block design (DBC) with 25 treatments (clones) with 3 replications and up to 12 cashews per plot (four plants in total). The results were submitted to the normality and heterogeneity of variance test, and then the F test was performed, which showed significant difference between the evaluated clones. The analysis of variance (ANOVA) was performed using the Genes software, and for the comparison of the means, the Scott and Knott test at 5\% probability was used. Differences were considered significant when $P \leq 0.05$ (Banzatto and Kronka, 2013).

Table 1. Identification of treatments and material origin.
\begin{tabular}{|c|c|c|c|}
\hline Treatment & Plot & Clones & Material origin \\
\hline 1 & $101 / 206 / 312$ & $113-1$ & Hibr. MG Resinose 2007 \\
\hline 2 & $102 / 209 / 315$ & MG-1 & MG 2005 \\
\hline 3 & $103 / 217 / 321$ & MG-17 & MG 2005 \\
\hline 4 & $104 / 212 / 302$ & MG-41 & MG 2005 \\
\hline 5 & $105 / 203 / 316$ & MG-57 & MG 2005 \\
\hline 6 & $106 / 210 / 308$ & MG-65 & MG 2005 \\
\hline 7 & $10 / 207 / 313$ & MG-76 & MG 2005 \\
\hline 8 & $108 / 224 / 311$ & $108 / 6$ & Progênies Pacajus 2007 \\
\hline 9 & $109 / 204 / 307$ & $146 / 7$ & Progênies Pacajus 2007 \\
\hline 10 & $110 / 218 / 309$ & SLC 12-20 & Exp. Clones Anão 1998 \\
\hline 11 & $111 / 201 / 322$ & $116-2$ & Progênies Pacajus 2007 \\
\hline 12 & $112 / 225 / 324$ & $114 / 2$ & Progênies Pacajus 2005 \\
\hline 13 & $113 / 220 / 320$ & $114 / 4$ & Progênies Pacajus 2005 \\
\hline 14 & $114 / 202 / 303$ & $133 / 1$ & Progênies Pacajus 2005 \\
\hline 15 & $115 / 219 / 306$ & $149 / 1$ & Progênies Pacajus 2005 \\
\hline 16 & $116 / 223 / 319$ & $105 / 5$ & Progênies Pacajus 2007 \\
\hline 17 & $117 / 215 / 305$ & $143 / 7$ & Progênies Pacajus 2007 \\
\hline 18 & $118 / 213 / 310$ & H-51 & Híbr. MG Resinose 2007 \\
\hline 19 & $119 / 222 / 317$ & H-71 & Híbr. MG Resinose 2007 \\
\hline 20 & $120 / 221 / 325$ & $155 / 2$ & Progênies Pacajus 2007 \\
\hline 21 & $121 / 205 / 323$ & END II 6-9 & Clone \\
\hline 22 & $122 / 211 / 318$ & PR0 805/4 & Clone \\
\hline 23 & $123 / 216 / 314$ & BRS 189 & Cultivar \\
\hline 24 & $124 / 214 / 304$ & CCP 76 & Cultivar \\
\hline 25 & $125 / 208 / 301$ & BRS 226 & Cultivar \\
\hline
\end{tabular}

\section{RESULTS AND DISCUSSION}

The statistical analysis revealed a significant effect from the treatments (clones) on all evaluated characteristics. Because of the large number of clones, it was convenient to separate them into groups to facilitate an understanding of the results. The criterion of separation in groups was the significant difference between them, which followed a decreasing order of the means, that is, group 1 will always present clones with higher averages for the variables. Each group consisted of clones that did not differ from each other. Depending on the analyzed variable, the number of groups changed according to the need to group clones with the same importance. The clones have always been compared to the control since it has the 
characteristics desired for natural consumption and processing markets.

The total mass (MT) of cashew varied from 66.45 to $143.36 \mathrm{~g}$, with a $76.91 \mathrm{~g}$ amplitude and a general average of $105.53 \mathrm{~g}$ (Fig. 1). However, the classification of the cashews was based on the number of fruits per tray, which usually ranged from 4 to 9 , corresponding to an average total mass of $600 \mathrm{~g}$ (Moura et al., 2015).

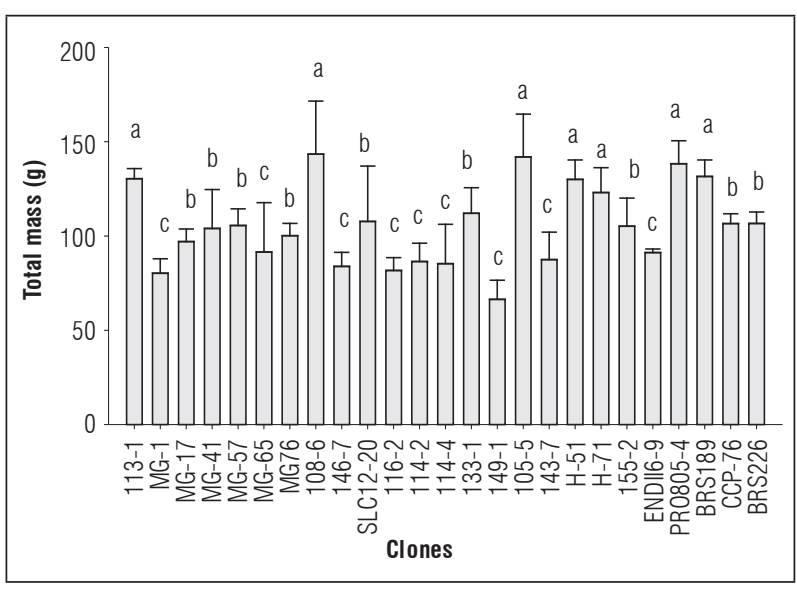

Figure 1. Total mass of cashews of dwarf cashew clones from Cruz, CE. 2017. Averages followed by the same letter do not differ from each other according to the Scott and Knott test $(P \leq 0.05)(n=3) \pm$ standard error. Values between 113.27 and $\mathbf{1 5 0 . 8 2}$ g are considered ideal.

In the present study, the clones 108-6, 105-5, PRO8054, BRS189, 113-1, H-51 and H-71, of this group had values between 102 and $143.36 \mathrm{~g}$ and were classified as type 4 cashews / tray. Group 2 (the control CCP-76 (106.57 g), 133-1, SLC12-20, BRS226, MG-57, 155-2, MG41, MG17 and MG76) had TM values that were 97,07 to $112.07 \mathrm{~g}$ and clones classified as type 5 cashews / tray. Group 3 (MG-65, ENDII6-9, 143-7, 114-2, 114-4, 146-7, 116-2, MG-1 and 149-1) had TM values between 66.45 and $91.49 \mathrm{~g}$ and clones classified as type 6 .

In general, the present study showed that the objectives of genetic improvement of dwarf cashew clones are being reached since the values of type 4, 5 and 6 (4, 5 and 6 cashews per tray.) are considered the market standard because they were obtained by evaluating the variable TM.

Thus, Moura et al. (2001), working on the physical characterization of peduncles of cashew clones for natural commercialization, obtained average masses for the cashews in a study with nine clones that ranged from $88.5 \mathrm{~g}$ to $155.4 \mathrm{~g}$; the maximum value of BRS 189 clone was lower to that found in this study.

For the CCP76 control in the aforementioned studies, they found values of 150.8 and $155 \mathrm{~g}$ (respectively) for TM; this clone is the mass standard for natural commercialization. However, they were superior to those found in this study for this same clone, possibly because first experiment was irrigated and the second work was carried out in 2006, which presented annual rainfall $(1,151.2 \mathrm{~mm})$, the annual average of the year of accomplishment of this work, 2017 (190.2 $\mathrm{mm}$ ) (Moura et al., 2001).

Lopes et al. (2011), working with the physical characterization of peduncles of dwarf cashew clones at different maturation stages, obtained average masses for cashews that varied from $80.28 \mathrm{~g}$ (BRS 189) to $83.72 \mathrm{~g}$ (CCP 09). The value of the BRS 189 clone was lower than that found in this study. On the other hand, when evaluating the clones CCP 76 and BRS 265 , which had the highest and the lowest mean of total mass, 113.27 and 54.36 g, respectively, CCP76 presented an average value higher than that found in this study, probably because of the local climatic conditions of the studied areas.

The present study showed that a variation of 55.01 to $130.64 \mathrm{~g}$, with an amplitude of $75.63 \mathrm{~g}$ and an overall mean of $95.16 \mathrm{~g}$ (Fig. 2), was observed for the peduncle mass (PM). Group 1 (108-6, 105-5, PRO8054, BRS189, 113-1, H-51 and H-71) was composed of clones with a higher PM, and the values of this group were between 112.43 and $130.64 \mathrm{~g}$. It is important to highlight that they obtained higher values than the control. Group 2 (the CCP-76 control (98.39 g)) next to clones 133-1, BRS226, MG-57, MG-41, MG17, SLC12-20, 155-2 and MG76). They presented variations for averages between 87.77 and $101.33 \mathrm{~g}$, inferior to group 1 and superior to the other groups. Group 3 (114-2, MG-65, ENDII6-9, 143-7, 146-7, 1144, 116-2, MG-1 and 149-1) had PM averages between 55.01 and $82.16 \mathrm{~g}$. The CCP 76 clone was studied by other authors. Comparing the two studies, it is possible to see that, in the first case, the clone obtained values of $92.7 \mathrm{~g}$, lower than the one found in this study (Pereira et al., 2005).

On the other hand, it was higher than the one obtained in this study, with an average of $172.5 \mathrm{~g}$ (Lopes et al., 2011), which can be explained by the high rainfall 


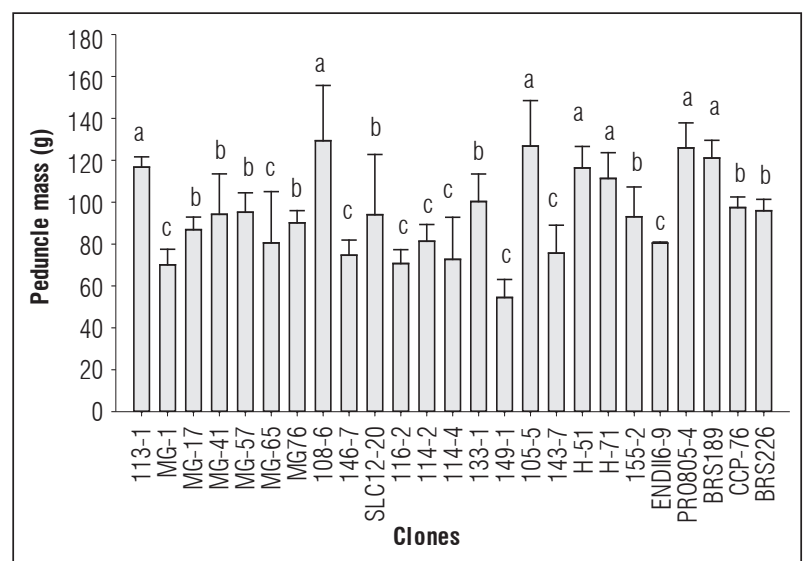

Figure 2. Peduncle mass of cashews of dwarf cashew clones from Cruz, CE. 2017. Averages followed by the same letter do not differ from each other according to the Scott and Knott test $(P \leq 0.05)(n=3) \pm$ standard error. Values between 101.03 and $141.80 \mathrm{~g}$ are considered ideal.

of $1,925.2 \mathrm{~mm}$ during the course of the experiment, about 10 times more than the rainy season during the present study. It is worth mentioning that the area of the experiment was also different, so possibly other factors may also have been involved in these differences.

Abreu (2007), when analyzing clones CCP 76 and BRS 226, obtained PM values of 145.80 and 144.52 $\mathrm{g}$, respectively, values higher than those found in this study because of the difference in the amount of water received by the plants in the rainy season since it was also done under dry conditions. In order to provide greater gains in the processing of the peduncle, cashews with higher MP values are much more attractive since processing industries look for a greater yield of pulp.

The differentiation of the peduncles between clones is important so that there is separation and standardization during the process of directing for export and supplying the various markets. Standardization makes the economic exploitation of this product more attractive because of the ease in choosing the type of peduncle that meets consumer need.

According to the present study, there was a variation of 8.18 to $15.08 \mathrm{~g}$ in the mass of the cashew nuts (CM) of the different dwarf cashew clones, with an amplitude of $6.9 \mathrm{~g}$ and a general average of $10.79 \mathrm{~g}$ (Fig. 3). Group 1 (114-2 and 105-5) was composed of

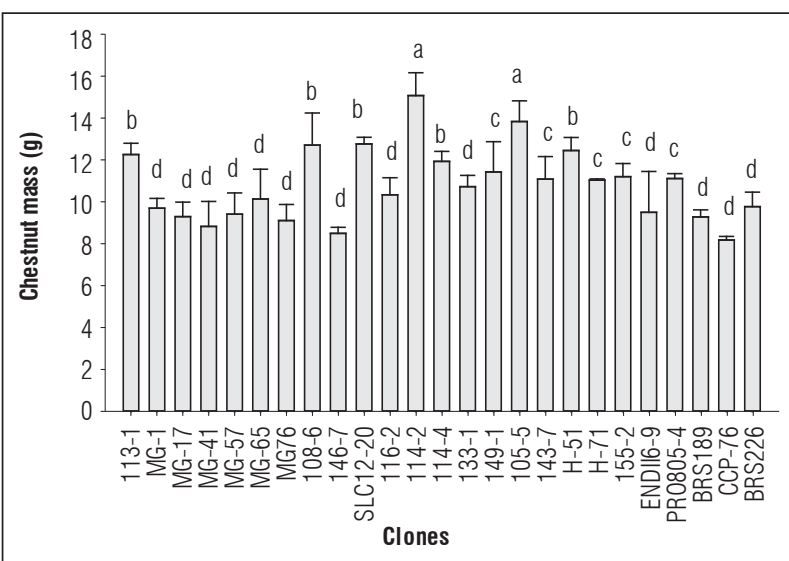

Figure 3. Chestnut mass of cashews of dwarf cashew clones from Cruz, CE. 2017. Averages followed by the same letter do not differ from each other according to the Scott and Knott test $(P \leq 0.05)(n=3) \pm$ standard error. Values between 9.02 and $11.47 \mathrm{~g}$ are considered ideal.

the clones that reached the highest CM values, which were 13.84 to $15.08 \mathrm{~g}$, higher than the control. Group 2 was composed of clones (SLC12-20, 108-6, H-51, 113-1, and 114-4), which presented values between 11.94 and $12.77 \mathrm{~g}$ and also stood out when compared to the value of the control. Group 3 (149-1, 1552, PRO805-4, 143-7 and H-71) had clones with CM values that were between 11.04 and $11.43 \mathrm{~g}$, standing out from the control. The control CCP 76 was used as the control group (133-1, 116-2, MG-65, BRS226, MG-1, ENDII6-9, MG-57, MG17, BRS189, MG76, MG 41 and 146-7), which presented MC values between 8.18 and $10.73 \mathrm{~g}$; the control had the lowest. Among the groups mentioned, 1, 2 and 3 can be highlighted because of large-sized almonds, which are appreciated by the chestnut processing industries because of the excellent mass, which may provide type SLW almonds (Special Large Whole) and corresponds to 180 almonds $/ 453.59 \mathrm{~g}$ (the minimum yield of almond for commercial production is $20 \%$ of the mass of the chestnut).

In a study evaluating the physical attributes of peduncles from different clones at different stages of maturation, it was observed that CCP 76, at stage 7 (commercial maturation), obtained results superior to the other clones with $11.21 \mathrm{~g}$, higher than that found in this study (Lopes et al., 2011). Analyzing a comparative ecology of two clones grafted under irrigation conditions found for CCP 76 nuts at the commercial maturation stage produced values varying from 6.9 
to $8.4 \mathrm{~g}$, similar values to that found for the same clone in the present study. These differences in MC were due to the difference in the amount of cashews that were produced from the same inflorescence (Lopes et al., 2011).

However, in the present study, cultural practices were not applied, such as pruning and thinning, in order to control the size and mass of the fruits, with development of more fruits on the same branch. These fruits tended to be smaller and, consequently, had a lower mass, which may explain these differences.

Among the studied variables, the size of the peduncle was directly related to three measurements: basal diameter (near the chestnut), apical diameter and length. It was observed that there was a variation of 42.21 to $58.38 \mathrm{~mm}$ for basal diameter (BD) for the different dwarf cashew clones, with an amplitude of $16.17 \mathrm{~mm}$ and an overall average of 50.07 mm (Fig. 4).

Group 1 (PRO805-4, 108-6, H-71, 105-5 and 133-1) had the best $\mathrm{BD}$ values, in a range between 54.47 and $58.38 \mathrm{~mm}$, superior to the control. Group 2 (clones BRS226, 155-2 and MG-41 together with CCP 76 $(54.10 \mathrm{~mm})+$ ENDII6-9) had BD values between 51.72 and $53.03 \mathrm{~mm}$, lower than group 1 and higher than groups 3 and 4. Group 3 (H-51, 143-7, 113-1, SLC12-20, MG-57, 114-2, MG-17 and MG76) was composed of clones expressing $\mathrm{BD}$ values between

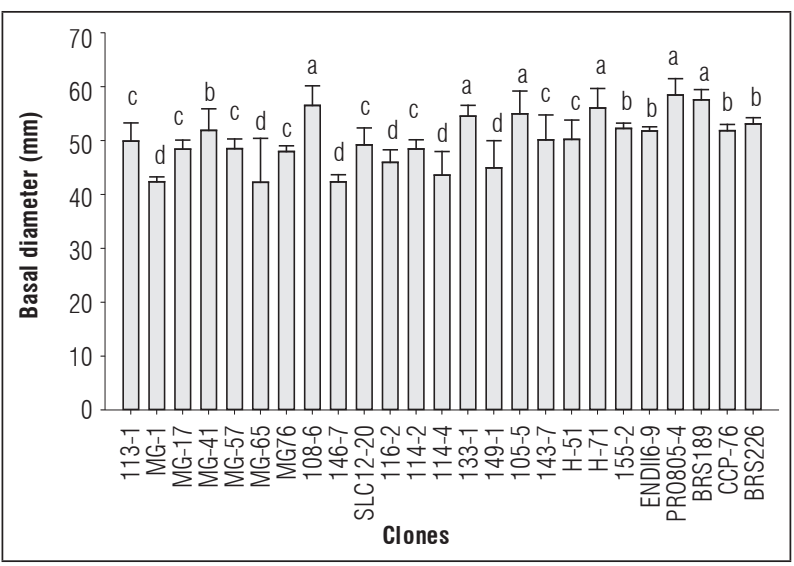

Figure 4. Basal diameter of peduncles of dwarf cashew clones from Cruz, CE. 2017. Averages followed by the same letter do not differ from each other according to the Scott and Knott test $(P \leq 0.05)(n=3) \pm$ standard error. Values between 53.73 and $61.82 \mathrm{~g}$ were considered ideal.
47.91 and $50.17 \mathrm{~mm}$, lower than the control and superior to group 4. Group 4 (116-2, BRS 189, 1491, 114-4, MG-1, 146-7 and MG-65) had clones with lower $\mathrm{BD}$ values, ranging from 42.21 to $45.90 \mathrm{~mm}$.

Studying physical characteristics of different cashew clones, Gomes et al. (2006) found the highest values for clones CCP 76, BRS 189, Embrapa 50 and Embrapa 51, 58.1; 57.6; 54.7 and $54.7 \mathrm{~mm}$, respectively. Values higher than those found in this study.

Abreu (2007), studying the quality and total antioxidant activity of peduncles of commercial clones of dwarf cashews, obtained a general average of 57.68 $\mathrm{mm}$, whose variation was from 50.63 to $61.97 \mathrm{~mm}$. Therefore, the values were higher than those found in this study. On the other hand, Lopes et al. (2011) found even higher values for CCP 76, $65.87 \mathrm{~mm}$.

For the variable apical diameter $(\mathrm{AD})$, a variation of 30.97 to $49.46 \mathrm{~mm}$ was found, with an amplitude of $18.49 \mathrm{~mm}$ and an overall mean of $41.38 \mathrm{~mm}$ (Fig. 5). The clones (BRS189, H-71, 155-2, 114-2, PRO805-4, 105-5, 133-1, BRS226, ENDII6-9, + clone 143-7 and SLC12-20) presented the highest $\mathrm{AD}$ values, between 42.15 and 49.46, standing out from group 2 (Tab. 1).

Group 2 (MG-41, H-51, 114-4, 149-1, 108-6, MG-57, 116-2, MG76, MG-1, 146-7, MG-65, MG-17 and 113 -1) presented $\mathrm{AD}$ values between $30.97 \mathrm{~mm}$ and 40.99 $\mathrm{mm}$, which presented lower values than group 1 .

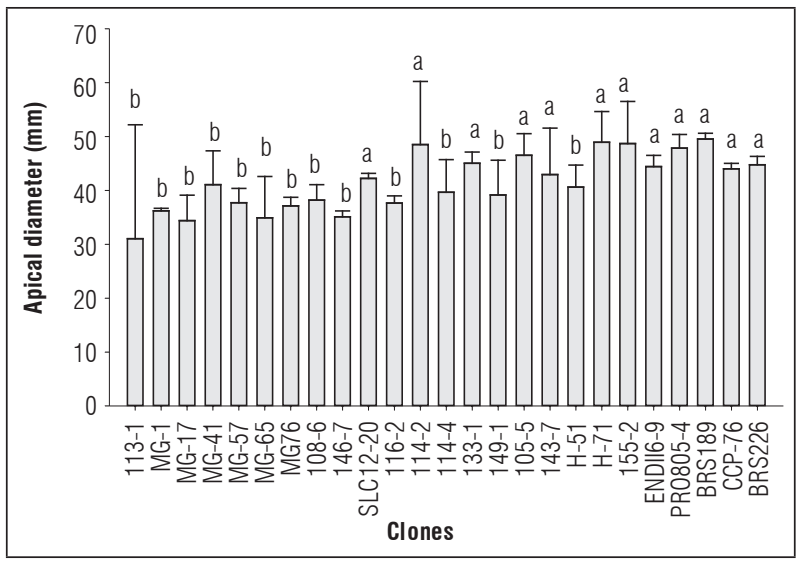

Figure 5. Apical diameter of peduncles of dwarf cashew clones from Cruz, CE. 2017. Averages followed by the same letter do not differ from each other according to the Scott and Knott test $(P \leq 0.05)$ $(n=3) \pm$ standard error. Values between 40.81 and $50.27 \mathrm{~mm}$ are considered ideal. 


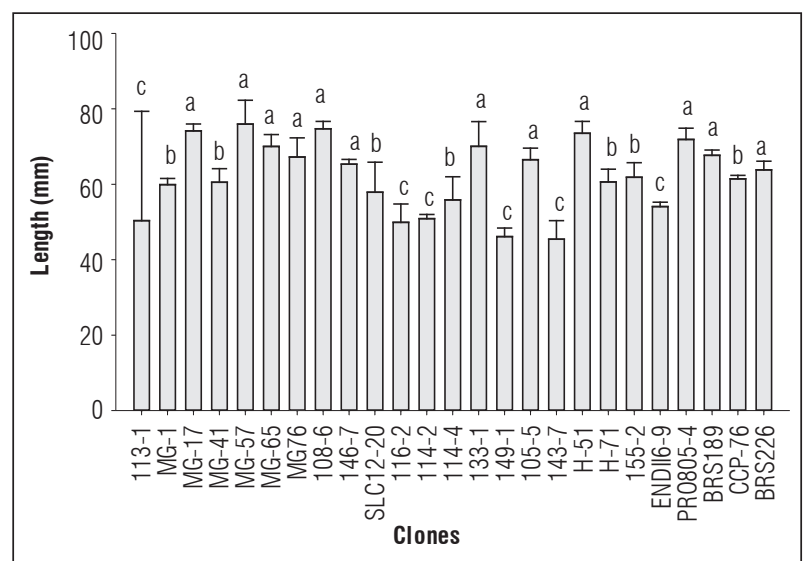

Figure 6. Length of peduncles of dwarf cashew clones from Cruz, CE. 2017. Averages followed by the same letter do not differ from each other according to the Scott and Knott test $(P \leq 0.05)(n=3) \pm$ standard error. Values between 67.24 and $76.44 \mathrm{~mm}$ are considered ideal.

Working with CCP clone 76, Pereira et al. (2005), in the Northern Region of Minas Gerais, obtained an $\mathrm{AD}$ value higher than $44.40 \mathrm{~mm}$. In the present study, the $\mathrm{AD}$ obtained for the same clone was 43.93 $\mathrm{mm}$. It was observed that, for the commercial stage, there was an average variation of 33.99 to $48.87 \mathrm{~mm}$ (Lopes et al., 2011), lower than the variation found in this study. When analyzing the peduncle length, a variation of 45.54 to $76.11 \mathrm{~mm}$ (Fig. 6) was observed, with an amplitude of $30.57 \mathrm{~mm}$ and an overall mean of $62.37 \mathrm{~mm}$.

Group 1 was composed of clones (MG57, 108-6, MG-17, H-51, PRO805-4, 133-1, MG-65, BRS189, MG76, 105-5 and 146-7) and presented the highest medium lengths, with values varying from 63.96 to $76.11 \mathrm{~mm}$, standing out from the other clones, including the CCP 76 control. Group $2(155-2+$ the CCP-76 control (61.56) next to clones H-71, MG-41, MG-1, SLC12-20 and 114-4) showed values ranging from 55.97 to $61.99 \mathrm{~mm}$, inferior to group 1. Group 3 (ENDII6-9, 114-2, 113-1, 116-2, 149-1 and 143-7) presented averages ranging from 45.54 to $54.19 \mathrm{~mm}$, less than the CCP 76 control.

In a study carried out by Lopes et al. (2011) on the physical attributes of peduncles of four different clones at different stages of maturation, it was generally observed that there was an increase in length during development for all clones. The mature CCP

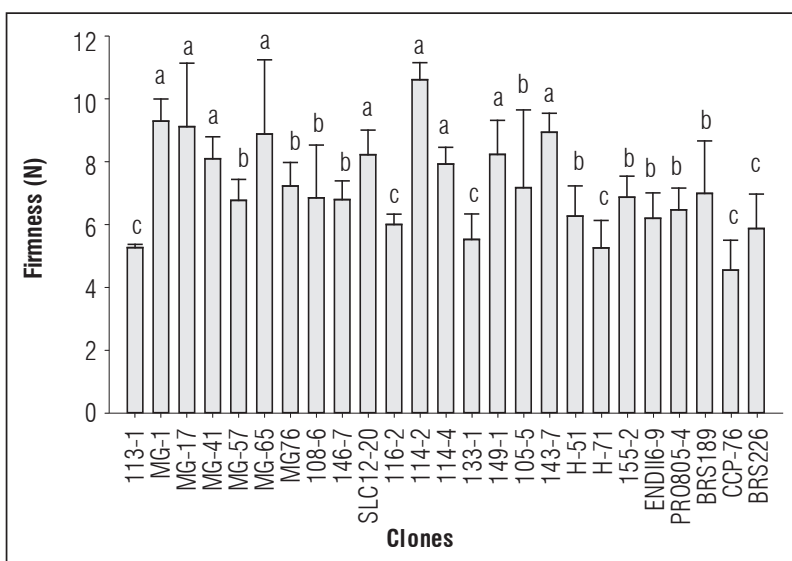

Figure 7. Average firmness of peduncles of dwarf cashew clones from Cruz, CE. 2017. Averages followed by the same letter do not differ from each other according to the Scott and Knott test $(P \leq 0.05)$ $(n=3) \pm$ standard error. Values between 5.83 and $16.19 \mathrm{~N}$ are considered ideal.

76 had the highest mean, with $67.24 \mathrm{~mm}$, which was higher than the length found for this same clone in the present study $(61.56 \mathrm{~mm})$.

As for firmness of the peduncles of the different clones of dwarf cashew, there was a variation of 4.57 to $10.67 \mathrm{~N}$, with an amplitude of $6.1 \mathrm{~N}$ and a general average of $7.22 \mathrm{~N}$ (Fig. 7). Group 1 (114-2, 114-4, MG-1, MG-17, 143-7, MG-65, 149-1, SLC12-20 and MG-41) was composed of clones that achieved the best firmness averages, with values between 7.97 and $10.67 \mathrm{~N}$, superior to the other groups and presenting greater resistance to mechanical damage. Group 2 (MG76, 105-5, BRS189, 155-2, 108-6, 146-7, MG-57, PRO805-4 H-516ENDII6-9) obtained firmness values ranging from 6.23 to $7.26 \mathrm{~N}$, higher than the control. Group 3 (116-2, BRS226, 133-1, 113-1, H-71 near the control (CCP-76)) showed the lowest firmness values, varying between 4.57 and $6.03 \mathrm{~N}$.

Pereira et al. (2005) found, for clone CCP 76, a firmness value in the central part of the peduncle of $16.95 \mathrm{~N}$, which, according to Almeida et al. (2011), was higher than any other study carried out with this clone in the commercial maturity stage. On the other hand, Lopes et al. (2011), studying the physical characterization of peduncles of dwarf cashew clones in different stages of maturation, observed a value of $7.78 \mathrm{~N}$ for CCP 76 in stage 7 , superior to the one found in this study for the same clone. 
Moura et al. (2001) assessed the physical characteristics of cashew peduncles for natural commercialization, which presented a value of $5.83 \mathrm{~N}$ for CCP76, superior to that found in the present study (4.57). Thus, studies have reported that peduncles with a greater firmness value have a longer post-harvest life, which was also sought in this study since it is one of the main objectives of researchers in this line of research.

\section{CONCLUSIONS}

For the variables total mass, peduncle mass, basal diameter and length, the best evaluated clone was 108-6 because it presented the highest average; however, when analyzing the nut mass and firmness, it was observed that they were better represented by clone 114-2. Clone 116-2 stood out for apical diameter. Overall, all clones showed good characteristics; however, clone 108-6 was better when evaluating total mass, peduncle mass, basal diameter and length, which stood out from the control (CCP 76).

In general, all clones presented good characteristics; however, clone 108-6 is preferred by most consumers since it has red staining, as does the control (CCP 76). Therefore, all clones presented desirable characteristics for natural consumption and/or processing.

Conflict of interest: this manuscript was prepared and reviewed with the participation of all authors, who declare that there exists no conflict of interest that that puts at risk the validity of the presented results.

\section{BIBLIOGRAPHIC REFERENCES}

Abreu, C.R.A. 2007. Qualidade e atividade antioxidante total de pedúnculos de clones comerciais de cajueiro anão precoce. MSc thesis. University Federal of Ceara, Fortaleza, Brazil.

Almeida, M., W. Freitas, J. Sarmento, P. Moarais, and G. Silva. 2011. Qualidade pós-colheita de pedúnculos de cajueiro submetido a dois métodos de colheita e mantidos sob refrigeração. Rev. Verde Agroecologia Desenvolv. Sustent. 6(3), 168-173.

Almeida, M.L.B., C.A.H. Moura, R. Inneco, and M.R.S. Silveira. 2018. Características físicas de pedúnculos de clones de cajueiro-anão (Anacardium occidentale L.) produzidos em função da variação ambiental e temporal. Rev. Colomb. Cienc. Hortic. 12(1), 41-49. Doi: 10.17584/rcch.2018v12i1.7509

Aular, J. and W. Natale. 2013. Nutrição mineral e qualidade do fruto de algumas frutíferas tropicais: goiabeira, mangueira, bananeira e mamoeiro. Rev. Bras. Frutic. 35(4), 1214-1231. Doi: 10.1590/S0100-29452013000400033

Banzatto, D.A. and S.N. Kronka. 2013. Experimentação agrícola. $4^{\text {th }}$ ed. FUNEP, Jaboticabal, Brazil.

Gomes, J.C.M., N.W. Gomes, L.C.A. Silva, W.A. Lima, and J.M. Silva. 2006. Postharvest characterization of early dwarf cashew tree clones in Western Bahia. Bahía Agríc. 07(2), 76-80.

Lopes, M.M.A. 2011. Qualidade e atividade antioxidante total em pedúnculos de clones de cajueiros anão precoce em diferentes estádios de maturação. M.Sc. thesis. Universidade Federal do Ceará, Fortaleza, Brazil.

Lopes, M.M.A., C.F.H. Moura, F.A.S. Aragão, T.G. Cardoso, and J. Enéas Filho. 2011. Caracterização física de pedúnculos de clones de cajueiro anão precoce em diferentes estádios de maturação. Rev. Ciênc. Agron. 42(4), 914-920. Doi: 10.1590/S1806-66902011000400013

Moura, C.F.H., R.E. Alves, R. Innecco, H.A.C. Filgueiras, J.L. Mosca, and S.A.A. Pinto. 2001. Características físicas de pedúnculos de cajueiro para comercialização in natura. Rev. Bras. Frutic. 23(03), 537-540. Doi: 10.1590/ S0100-29452001000300017

Moura, C.F.H., R.E. Alves, E.O. Silva, and M.M.A. Lopes. 2015. Fisiologia e tecnologia pós-colheita do pedúnculo do cajueiro. $3^{\text {th }}$ ed., revised and expanded. Embrapa Agroindústria Tropical, Fortaleza, Brazil.

Pereira, M.C.T., H.C.T. Correa, N.S. Silvia, W.F. Mota, and S.V. Marques. 2005. Caracterização físico-química de pedúnculos e castanhas de clones de cajueiro-anão precoce nas condições do norte de Minas Gerais. Bragantia 64(2), 169-175. Doi: 10.1590/ S0006-87052005000200001

Wang, G.Y., X.Z. Zhang, Y. Wang, X.F. Xu, and Z.H. Han. 2015. Key minerals influencing apple quality in Chinese orchard identified by nutritional diagnosis of leaf and soil analysis. J. Integr. Agr. 14(5), 864-874. Doi: 10.1016/S2095-3119(14)60877-7 